\title{
A Comparative Study of the English Versions of The Analects by Legge and Ku Hungming
}

\author{
Lihua Yang \\ School of Foreign Studies, Yangtze University, Jingzhou, China
}

\begin{abstract}
The Analects is one of the great works of traditional Chinese culture, and its translation has been an important part of cultural exchange in the past hundred years. The English versions of the Analects have reached more than 40, including that of James Legge's and Ku Hungming's. James Legge was a missionary and a famous British Sinologist; Ku Hungming was a famous Chinese scholar who got educated in the west. Their versions represent the highest level at that time. Legge is known for his rigorous responsibility to the original text, "faithful to the original". His version is of a scholar translation style, which can be summed up as "truthfully, lengthy and dull." Ku Hungming was renowned at home and abroad for his unique and weird style in Qing Dynasty. He received Western education and was deeply influenced by Western Romanticism. Most of his articles are written in English, even the native English speakers feel surprised by his extraordinary English proficiency. Ku also made great achievements in imputing Chinese classics to the west. In order to make the content easily acceptable to the Westerners, he tried his best to avoid Chinese names and places, and in order to evoke the original idea of the readers, he widely cited the western allusions and famous sayings. So Ku's translations are widely spread in Europe. This paper focuses mainly on three parts. First, the translation differences of the two versions are investigated from the language to the overall translation techniques. Then, the causes of differences are analyzed, which include cultural background, Sinology skills, purposes and audience awareness. Finally, the way to translate Chinese classics like The Analects is briefly summarized.
\end{abstract}

Index Terms - The Analects, translation, contrast, Legge, Ku Hongming

\section{INTRODUCTION}

Having been at the core of Confucianism, The Analects is a masterpiece of the Chinese classical works and has played a far-reaching role in cultural communications between China and the western countries for a long time. According to the statistics, there are nearly more than 40 English versions produced by westerners and Chinese scholars in the past 100 years, among which two versions are commonly considered the most classical and representative: One is The Analects translated by Ku Hungming (1857-1928) who is a Chinese scholar educated in Britain, and the other is The Confucius Analects translated by Legge (1815-1897) who is a famous British missionary. For the following reasons, we select these two versions. First of all, both of the two translations are among the most classical and influential ones, which are popular among their target readers for the outstanding features; secondly, the two versions apply diverse translating strategies in light of special translation purpose, taking into consideration the language art and cultural factors. What's more, Ku Hungming and Legge, coincidentally or not, coming from east and west and living at the same period, made great contributions at the turning point of translation from missionaries to sinologists with a lot of western scholars stepped into Chinese culture, which is of tremendous importance in translation of The Analects.

\section{ANALYSIS OF ENGLish Versions by JAMES LEGGE AND Ku HuNG-Ming}

\section{A. Contrast on Language}

Translation of the main concept words in the two English versions of The Analects is an important part to study the differences. According to manipulation translation theory, translation is a process of making decisions. Comprehension and translation of the main concept words of The Analects of Confucius can reflect the rewriting strategies and cultural attitude on original text as a whole. In The Analects of Confucius, the "ren" appears 109 times. Confucius regards "ren" as the basis of other virtues. For example, in Xueer, he points out the relationship between filial piety and benevolence; In $\mathrm{Ba}$ he points out the relationship between benevolence, ritual and music; In Xianwen he talks about the relationship between kernel and brave; In Yanghuo he points out that "gong", "kuan", "xin", "min" and "hui" is the basis of kernel . Thus we can see that "ren" has a profound humanitarian content. Legge and Ku rewrite "ren" respectively according to their own consciousness of history and culture. Legge translates "ren" in the whole book as "virtue", "ren zhe" as virtuous man, and "de" also as "virtue" from the perspective of western culture and religion of humanity. Therefore, "virtue" has the highest frequency in its translation as a keyword. Due to his status as a missionary, "ren" in its vision is a virtue which includes many aspects. The frequency of the use of virtue and using "virtue" for "de" obviously reflects his moral concept. Perhaps Ku takes "ren" as an ethical morality concept for the following reasons: on the one hand, because of the deep relationship between "ren" and other Confucian virtue; on the other hand, Confucian spirit emphasizes the manner between the noble and the ordinary, husband and wife, and so on. Therefore, "ren" of the 
Confucian is an essentially ethical spirit. Ku translates "ren", "junzi", "de", "he" into "moral", "morality", "the moral man", and "the moral law". He grasps the essence of Confucian culture, which is also precisely the foundation of his translation.

"li" appears 74 times in The Analects, and it is another important basis of Confucianism. "li" and "ren" is closely related. Confucian ritual is a kind of theory, not only refers to the specific ritual forms, but also means politeness, the ceremony and ethical system. From different levels, it can be divided into Confucianism, ritual teaching, and law etc. In all the contexts of The Analects, the meanings of "li" are not same. No wonder in the two versions of translation, "li" has very abundant meanings. Legge's translation of "li": ceremonies, courtesies, propriety, the rules of propriety. Ku's translation is as follow: courteous, art, the education and good manner, propriety, civilization, the correct form, the principle of the rite the honors, the man of the rules of taste, courtesy and good manners (yield), direct his studies with judgment and with courtesy, religion, education, and the polite arts (ritual, music), and so on. Therefore, the translation of $\mathrm{Ku}$ can enough reflect the diversification of the Confucian ritual connotation, on the semantic field corresponding to the ritual, this is due to his overall understanding of Confucian culture.

The following context can help us compare the two translators' translations.

1.子曰: “夏礼吾能言之, 杞不足征也; 殷礼吾能言之, 宋不足征也。”

Confucius here refers to "li" as an overall concept. Confucius stresses that gentlemen should know "liuyi", in which "li" is included. Legge takes "li" as the ceremonies, just a courtesy of a translation in terms of content, which is associated with religious form. $\mathrm{Ku}$ translate it into "the arts and civilization", which is more accurate with both the artistic content and the social continuity of ritual.

2. 颜渊问仁, 子曰: “克己复礼为仁。一日克己复礼, 天下归仁焉。”

To keep the ritual rules, to be strict to ourselves and to unify the ego and the big world, this is the base of "ren" policy. Here, “li" is a social code of conduct. Legge has “克己复礼” translated into “To subdue oneself and return to propriety is perfect virtue; this is the distorted understanding of Confucius' ideas. The translation of Ku's 'Renounce yourself and conform to the ideal of decency and good manners" is better.

\section{B. Translation Strategy}

As what has been mentioned above, translation involves not only transmission of language, but also interpretation of different cultures. Up to this date, two ways are used in translation elements, one is foreignization which takes culture of target language as its reference and the other is domestication which regards culture of original language as its reference. In translation of The Analects, they selected different translation strategies, that is to say, Legge prefers foreignization and Ku Hung-ming prefers domestication. Both James Legge and Ku Hung-ming are well aware that their target readers are those who do not get a very clear picture of ancient Chinese culture, accordingly many measures are taken by them for the sake of target readers. James Legge uses the translation strategy of foreignization, which aims at the western readers who come to China for missionary cause. First of all, the content, writing style, religious flavor and consciousness orientation of the original text are to a great degree preserved by James Legge. So this maintains the original meaning and styles of The Analects, providing idiomatic translated text for his target readers--missionaries who come to China to do missionary work, which would be convenient for them to read and get acquainted with Chinese culture so as to better promote their task. Then, the core terminologies, grammatical phenomenon are explained with notes when they appear at first time at the translated text. James Legge gives a detailed account of these core terminologies, such as “virtue (仁)", “filial piety (孝)", “be true to the principles of our nature (忠)", “the benevolent exercise of nature principle to others (恕)" and so on.

Last, James Legge combines semantic translation with detailed annotation, being attentive to the real requirements of those western readers not having a good picture of ancient Chinese culture. That is, with very detailed notes and forewords, elaborated information on background and personnel names, his English version offers the western readers a very good access to the extensive and profound ancient Chinese culture. James Legge makes annotation at the foot notes during the course of translation of The Analects, thus to facilitate the readers to get a good understanding of the very meanings of original text.

\section{CAUSES OF THE DiFFERENCES}

\section{A. Life Experience and Academic Background}

James Legge's and Ku Hungming's different life experiences and academic background to some extent lead to the differences of their unique understanding about the original version of The Analects and in the expressions of their English versions. James Legge, who was a Scottish sinologist and a missionary, spent nearly thirty years in China working as a missionary and translator. James Legge was born at Hadley town, Aberdeen shire, Scotland of UK. He was a member of the non-conformist Presbyterian Church that separated itself from the State Church in Scotland. Philosophically, Legge has been influenced mostly by Scottish Realism, which gave him the ability to have some deeper insights into the Confucian classics. He took more interest and curiosity in ancient Chinese classics when he began to learn about the ancient Chinese classics under the influence of British missionary, Milyn. Having received 
early years' training in religious studies, from 1831 to 1835 , James entered into Aberdeen Royal College for higher education. With time passing by, the willingness to work as the missionary in China came into being.

At his young time, James worked as the dean of Anglo-Chinese College. At the spare time he went on studying the ancient Chinese classics, and the mounting interest propelled him to initiate a great project that could enable the whole world to have a good understanding of China. Legge had a colorful life experience. For almost sixty years, he lived in London, Hong Kong, and other parts of the British Empire, working with an array of people, ranging from missionaries and scholars to merchants and book publishers. In his later life, he traveled widely: Southeast Asia, China, North America, and the British Isles. (Hon, 2006) In 1868, James Legge and his English translation assistant, Wang Tao, devoted themselves to the completion of translation of ancient Chinese classics at the Dollar County, Clackmannanshire, and Scotland.

In completion of the great task, Legge benefited much from his academic background. "There is no doubt that Legge's Scottish background - particularly his exposure to the Sabbath Culture in his childhood and his training in the common-sense philosophy in King's College - must have made him a sensitive and sympathetic translator." (Hon, 2006, p.458) $\mathrm{Ku}$ Hungming is the leading figure proficient in western and oriental cultures during the late Qing Dynasty and the early period of the Republic of China. His ancestral home is Fujian. On July 18, 1857, Ku Hungming was born at a British owned rubber plantation, Penang Pulau, north-western of Malaysia Peninsula, Southeast Asia. His father is the general manager of the rubber plantation, excelling in speaking English and Malay. His mother is a blond-haired and blue-eyed western woman, who has a good mastery of English and Portugal. Hence under such unique family background, $\mathrm{Ku}$ Hung-ming enjoyed remarkable capability in language learning and comprehension. He spent his teenage abroad, received systematic western education, and mastered multiple languages such as English, German, Greek and Latin, etc. The 14-year life of studying abroad enabled this super language-gifted youth to become a young scholar, having a good mastery of western culture. After obtaining the Master of Arts in 1877, Ku Hungming went to University Leipzig of Germany and other top colleges for further study in literature and philosophy. Upon returning to China after graduation, Ku Hungming had engaged in depth-study of Chinese culture for over two decades on learning more ancient Chinese classics. He got the unique insight into the traditional Chinese culture especially the Confucianism. Once he worked as the trusted aid and staff for Zhang Zhidong, a noted senior official in late Qing Dynasty. It is the prior difference in their life experiences and academic backgrounds that shapes their diverse understandings by their linguistic competence and their comprehension of the original version of The Analects.

\section{B. Sinology Capability and Bilingual Competence}

Translation of ancient classics demands both thorough profound comprehension of the original text and remarkable language ability. James Legge has a gift in acquiring language. Before coming to China he had learned Chinese and Chinese culture. After arriving at Malacca, he continued being engaged in the study of Chinese culture. Having been in China for a long period, James Legge was learned in sinology. Furthermore, he received the very aid from Wang Tao, a noted Chinese scholar and translator in the late Qing Dynasty. All this laid solid foundation of the completion of the English version of The Analects. Besides, as a British, fluent home tongue is his privilege. Later under the leadership of James Legge, the English versions of The Four Books and Five Classics in Confucian School including The Analects were all published. For dozens of years James was engrossed in the studying of the ancient Chinese classics. When it comes to the compilation of such classics, he would get the assistants to collect all the relevant remarks by the scholars from previous periods. At the foreword of "Seeing the Western Scholar-James Legge off before his departure from China", Wang Tao (2002) once wrote, "The English versions of The Four Books and The Book of History came into being". "Having going through them, the western scholars acclaimed all them so detailed and extensively-covered that they should be treated guide line to the study of the oriental culture." (p.81) Compared with English version of The Analects by James Legge, the English version by Ku Hungming enjoys a unique style of advantage. He is the most intelligent Chinese with great gift in language learning and composition. Although Ku Hungming once at youngster age stayed abroad for years, once returned to homeland he was engrossed in studying the ancient classics and dedicated himself to the great cause of the traditional Chinese culture. Shortly after back to China, he begun to make up for Chinese language, his proficiency in Chinese reached a much higher level ever later. Out of profound understanding and ardent love of the ancient Chinese classics, especially the Confucian classics, Ku Hungming keenly realized both the profound philosophy underlying the Confucian classics and its literature value, thus he was in high spirits to go in for the compilation of the English version of The Analects. However, out of proud stance Ku Hungming held a critical attitude towards the other English versions of The Analects. In his remarks, he said brilliant scholars, including James Legge lack acute comprehension not only in literature but also in sagacious insight; moreover, he thought James Legge's English version was not pretty satisfactory. Ku Hung-ming criticized James Legge's for "his stiff and totally incorrect account of Confucius's characters, morals and Confucianism". There is no doubt that those remarks were partially biased, but it also showed that Ku Hungming was much confident in his much learned sinology knowledge and super bilingual capability.

Indeed as a wide-read and scholarly man, Ku Hungming enjoyed the reputation for his excellence in studying of both western and Eastern culture, and people grasped in admiration for his achievements in English. Dr. Lin Yutang once praised $\mathrm{Ku}$, "His mastery of English surpasses the others for the past 200 years, whether in choice of either words or expressions". (Huang, 1995, p.6) Dr. Sun Yat-sen once remarked that at modern China there are three and half talents in 
English language, that is, $\mathrm{Ku}$ Hungming, Wu Chaoshu, and Chen Youren, and rated $\mathrm{Ku}$ as the No.1. Not only Chinese speak high of Ku Hungming's English competence, but also foreign scholars are much appreciative of his language proficiency. Soothill, William E. (1910) highly praised the English version of The Analects by Ku Hungming, "The learners shall owe thanks to $\mathrm{Ku}$, who is a well cultivated Chinese". He translated and deciphered the classics, which is highly valuable to all of us. (p. II-III.)

\section{Translation Purpose}

Translation strategy is in a way affected by translation purpose of the translator. To be exact, with different translation purposes, James Legge and Ku Hungming come up with different translation strategies.

As a loyal missionary and a noted British sinologist as well, James Legge's translation purpose was to help the western missionaries coming to China have a better understanding of The Analects, and to promote their great cause. In his words, "If a western missionary in China does not get a mastery of the ancient Chinese classics, nor does he make a personal probe into the ideology fields where the previous Chinese sages and men of virtue ever went, he is incompetent to the duties and preaching work he is supposed to take on". (Legge, 1893, p.45) James Legge hoped that the completion of the translation of The Analects could "enable other areas and regions of the world to get a genuine understanding of this great empire, particularly once our missionary cause in China is guided by the local ample cultural resources, its long-term effects could be ensured." (Cheng, 2002, p.17) Furthermore, "it helps the missionaries well comprehend the Chinese classics, extend our inner sympathy based on such deep understanding, thus that could defuse their hostility towards us foreigners, and finally guide the Chinese people to bound for the way looking for another sage, let Confucius alone". Accordingly he required that the translated text "should be loyal to the original text, not uphold the colorfulness of the target text so much" (Legge, 1893, p.89). In order to comply with the rationale of being loyal to the original text, James Legge not only employs literal translation-stressing on reserve of phrasing and sentence patterns of the original text", trying to keep a original flavor of the source language, but also would rather neglect smoothness and fluency of the source text than make any adjustment. Judging from James Legge's language gifts, it's not that all this cannot be conducted by his own capability, but that he did it on purpose. The main purpose of his translation is to display "the peculiar manner of writing of the original text". (Wang, 2003, p.69) When it comes to Ku Hungming, two factors or purposes motivated him to compile the English version of The Analects. The first one is that obviously $\mathrm{Ku}$ Hungming was unsatisfied with that of The Analects complied by western scholars. He said at the prologue of the English version of The Analects, "It's over 40 years since Dr. James Legge published the first section of his English version of Ancient Chinese Classics. Now anyone, even if those who knows nothing about Chinese language, cannot help thinking that his translation text is so discontent to the common people as long as he or she takes some time patiently going through Dr. James Legge's works." (Ku, 1996, p.345) As Ku Hungming (1996) said, "The common British people will consider much strange and odd the Chinese's wisdom and virtues embodied in the translated text of James Legge, just as the same feelings the westerns have when they see the Chinese wearing such traditional clothes as robes and mandarin jackets." (p.345-346) The second purpose for Ku Hungming to start recompilation of The Analects is that he strongly wanted to reshape the westerners' attitude towards the whole China whether in terms of Chinese people or in terms of international communication. Living in the late Qing Dynasty and the early period of the Republic of China, Ku Hungming saw that at that time China was faced with domestic strife and foreign aggression, and the western culture was holding the dominant position in China. With years' experiences of studying abroad at youth as well as years' concentrated research of the Confucian culture, Ku Hungming deemed that " The Analects is the inherent cultural treasure of our great China, and we shall have the very duty to present it to the westerners" (Huang, 1995, p.27). British people can "reflect upon those preconceived ideas towards our Chinese after going through patiently this English version of The Analects, hopefully, it helps to change their previous prejudices and bias towards both whole China and the Chinese individual during the international connections." (Ku, 1996, p.346-347)

\section{CONCLUSION}

From what we discussed above, we can find out that translating classic literature works like The Analects is really a complex process. Legge's and Ku's version can stand for two different style-heterization and naturalization, however, it seems impossible for us to tell which one is better. What the translator needs to do is to be more flexible. During the course of translation we can do better through combining history with present time, and the integration of the source text and the target text, the author and the translator, accordingly, the style of the source text can be better presented to the readers.

\section{REFERENCES}

[1] Cheng Gang. (2002). A Contrastive Analysis of the Semantic System in Legge and Walley's English Versions of Lun Yun. Journal of the Confucian Study 28.2, 17-18.

[2] Hon, Tze-ki. (2006). Striving for The Whole Duty of Man: James Legge and the Scottish Protestant Encounter with China Lauren F. Pfister .Journal of Chinese Philosophy 34.2, 57-61.

[3] Huang Xingtao. (1995). Ku Hung-ming: An Odd Talent. Beijng: Chinese Bookstore.

[4] Legge James. (1893). The Chinese Classics. Oxford: The Clarendon Press. 
[5] Ku Hungming. (1898). The Discourse and Sayings of Confucius. Shanghai: Kelly and Walsh, Ltd.

[6] Soothill, William E. (1910). The Analects of Confucius. New York: The F. H. Revell Company.

[7] Wang Tao. (2002). The Anthology of Tao Yuan. Shanghai: Shanghai Bookstore.

[8] Wang Hui. (2003). Legge and Chinese Classical Works. Journal of Chinese Translation 24.2, 39-43.

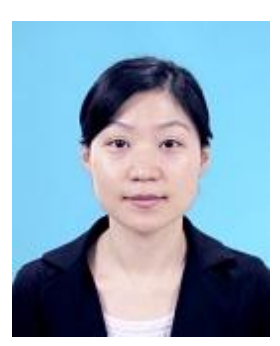

Lihua Yang was born in Fuzhou, China in 1982. She got her doctoral degree in 2012 at Foreign Studies College, Hunan Normal University (HNU), Changsha, China. Her major field is in translation studies. Her doctoral dissertation is "A Study of Lin Shu's Translation". She is currently a lecturer at School of Foreign Studies, Yangtze University. 